\title{
フィラメント強撚糸製造における加撚·撚止め工程の連続化
}

\author{
金沢大学工学部 新宅 救徳 \\ 石川県工業試験場 山本孝 \\ 金沢大学工学部 喜成 年泰
}

\section{LINKAGE OF TWIST AND SET PROCESS TO OBTAIN HIGHLY TWISTED FILAMENT YARN}

\author{
By Sukenori Shintaku*1, Takashi Yamamoto ${ }^{* 2}$, and Toshiyasu Kinari*1 \\ * 1 Department of Mechanical Engineering, Kanazawa University. \\ Kodatsuno, Kanazawa, 920 Japan \\ *2 Department of Textiles, Industrial Research Institute of Ishikawa \\ Prefecture, Tomizu-machi, Kanazawa, 920-02 Japan
}

\begin{abstract}
The package enlargement and the increase of production speed have great advantages in the manufacture of highly twisted filament yarn. A new twisting system was proposed in this paper consisting of a flyerless twister containing a false twist spindle, a ring twister, a heater to set yarn and anoter false twist spindle $\left(F_{2}\right)$. This twisting system could produce highly twisted yarn without knots wound to a large package. The use of $F_{2}$ was profitable to reduce the tension of the yarn on the heater. The snarl index of highly twisted yarn was also reduced when $F_{2}$ was revolved faster than the ring twister spindle. The yarn, set to higher twisted state by $F_{2}$ and untwisted to the final twist number, had lower torque than that of the yarn with the same twist level obtained by the system without $F_{2}$. This procedure showed no effect on the twist contraction and heat shrinkage. By this twisting system, twisted yarn with the same level of snarl index as that of yarn produced by the system without $F_{2}$ was obtainable at lower set temperature. The yarn of lower crystallinity was set to lower torque level, and the fineness of the obtained yarn increased owing to the large heat shrinkage.
\end{abstract}

(Received July 18, 1989)

\section{1. 粕 言}

強然系を製造するにあたって，工程の高速化とラージ パッケージ化は重要な技術的課題となっている。また, 強撚系慗造の場合には加撚工程の後，撚りトルク莫潜在 化して製蟣し易くするため撚此め工程が不可欠である。 撚止め工程の条件によって，織物となったときの撚りト ルクの発現が猉なり，風合に富んだ織物が得られるが， 一方、微妙な糸管理ミスが織物欠点の原因となっている ${ }^{1,2)}$ 。これらの問題を解決する方法として，加撚と撚止 めを連綍して行うためにヒータを装備したダブッイス $タ^{3)}$ が考案されている。また既存の機構を組み合わせて 合理化を图った類似の例として，仮撚と合撚を連続して
行うもの仿ある。このように加工工程を連続にすると 変化する条件が多くなるため，従来の場合との差異を明 らかにしておく必要がある。

本研究では強撚系製造の高速化とラージパッケージ化 をはかる方法として，2固の加撚機構と撚止めとー夕お よび仮撚スピンドルを持つ撚系機を試作し，この撚糸機 構で製造された強撚系の物性について実験し，加撚工程 と撚止め工程を連続化することによって得られる利点に ついて检乵した結果を報告する。

\section{2. 実験装置および実呀方法}

\section{1 加然·然止め連続化然系機について} 試作した装置の概略因を图1に示す。第 1 加撚部とし 


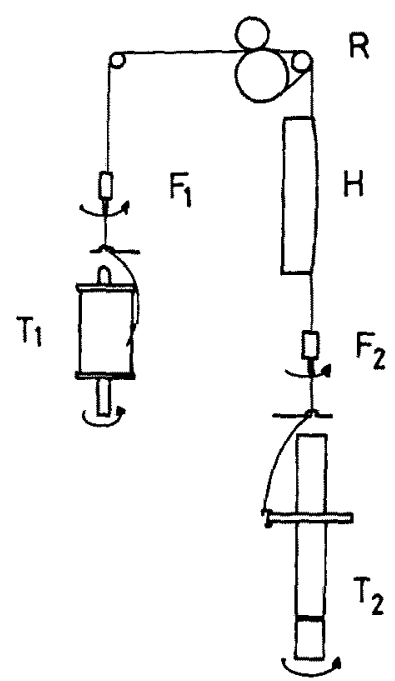

Fig. 1. Schematic illustration of twisting system (a). $T_{1}$. First twist spindle; $F_{1}$, first false twist spindle; $T_{2}$, second twist spindle; $F_{2}$, second false twist spindle; $R$, feed roller; and $\mathrm{H}$, heater. In the twisting system (b), a two-for-one twister was used in place of $F_{1}$ and $T_{1}$ in order to increase the production speed.

てフライヤーレス撚系機，撚止め部として長さ $303 \mathrm{~mm}$ で曲率半径 $2 \mathrm{~m}$ のヒータ，仮撚スピンドル，そして，第 2 加撚部お゙よび巻取り部としてリング撚系機を組み合わ せている。このようにアップ型とダウン型の撚系機を併 用したものを複式撚系機と呼び，人絹強撚糸用に適す るらと言われる。本装置におけるヒータによる撚止めの 主目的は一時的にスナールの発生を防止し，製織工程で の作業性を良くすることであり；仮撚系の場合のように 完全に糸のトルタを緩和してしまうことが目的ではな W。

本試作機の特徽はヒータとリング撚糸機の間に仮然ス ピンドルを設けていることである。このスピンドルに は、リング然系機で系にかかる張力が直接ヒー夕部の糸 にかからないようにする動きがあり，さらにこの仮然ス ピンドルの回転数を制御することによってヒータ上の撚 系の然数を自在に変えることができる。すなわち，中間 にある仮撚スビンドルの回転数 $\mathrm{n}_{\mathrm{f} 2}$ がリング撚系機のス ピンドル回転数 $\mathrm{n}_{\mathrm{s} 2}$ より大きいとその分だけ $\mathrm{R}-\mathrm{F}_{2}$ 間での 撚数が設定撚数より大きくなり， $\mathrm{F}_{2}-\mathrm{T}_{2}$ 間で逆に解然さ れて巻取られる。一方， $\mathrm{n}_{2} か ゙ n_{\mathrm{s}}$ より小さいときはその 分だけ R-F 間での撚数が設定撚数より少なくなり， $F_{2}-T_{2}$ 間でさらに追撚されることになる。このように $n_{\mathfrak{f} 2}$

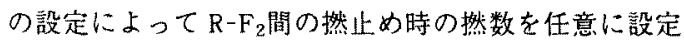
することができるという特徴をもっている。
第 2 加撚と巻取りを行うリング然䋆機 $\mathrm{T}_{2}$ は、，最大系 巻質量 $3 \mathrm{~kg}$ のパーン巻きが可能であり， ラージパッケ 一ジ化に対応できる。またただちにジェットルームの よこ采としても解じょに問題はない。一般的にリング撚 糸機は生産性の点で問題があるが, 本機の場合は他の撚 系機構と組み合わせ，加撚を分割して行うために竹で 加撚する撚数が少なくなり，従って生産速度を速くする ことができる。また，通常のリング撚系機で強撚糸を製 造する場合，スナールがトラベラを引っかける恐れがあ るが，本装置ではリング然系機に入る前に系を撚止めし ているために問題はない。

この機構で糸に加えられる撚数について考える。撚数 は以下系長 $1 \mathrm{~m}$ あたりで表す。第 1 加撚部で加撚される 撚数を $N_{1}$ ，第 2 加撚部で加撚される撚数を $N_{2}$ とする。 $\mathrm{N}_{1}$ は第 1 加撚部のスピンドルの回転数 $\mathrm{n}_{\mathrm{s}}$ と糸の送り速 度(フィードローラの速度) $\mathrm{V}(\mathrm{m} / \mathrm{min}) に よ っ て, ~ N_{2}$ は第 2 加撚部のスピンドル回転数 $\mathrm{n}_{2}$ と巻取速度 $\mathrm{V}_{\mathrm{t}}(\mathrm{m} / \mathrm{min})$ によって表される。また、ワインディングおよび巻取り の巻角を $90^{\circ}$ ，第 1 ，第 2 加撚部のボビンの直径をそれ ぞれ $d_{b 1}, d_{b 2}$ とすれば

$$
\begin{aligned}
& N_{1}=n_{s 1} / V+1 /\left(\pi d_{b 1}\right) \\
& N_{2}=n_{s 2} / V_{t}-1 /\left(\pi d_{b 2}\right)
\end{aligned}
$$

となる。式(1)の右辺第 2 項は第 1 項に比して小さいた め省略され，式( 2 )の右辺第 2 項は解じよの㻮に相殺さ れる。また，卷取り速度 $V_{\mathrm{t}}$ は機械条件から設定でき ず，合撚機では然数が少ないので然縮みが小さいことか らフィードローラの速度が基準となっている。そこで， 本研究では次式で機械撚数 $\mathrm{N}_{\mathrm{m}}$ を定義する。

$$
\mathrm{N}_{\mathrm{m}}=\left(\mathrm{n}_{\mathrm{s} 1}+\mathrm{n}_{\mathrm{s} 2}\right) / \mathrm{V}
$$

一方，本奏験では強撚系を製造しているので，加竢中 にかなり大さな撚絔みが発生する。このためV、はVよ りかなり小さくなり，実際に製造された系の撚数 $\mathrm{N}_{\mathrm{y}}$ は

$$
\mathrm{N}_{\mathrm{y}}=\left(\mathrm{n}_{\mathrm{s} 1}+\mathrm{n}_{\mathrm{s} 2}\right) / \mathrm{V}_{\mathrm{t}}
$$

であるから機械撚数 $\mathrm{N}_{\mathrm{m}}$ より多くなる。したがって実撚 数 $N_{y}$ と機械撚数 $\mathrm{N}_{\mathrm{m}}$ の関係を撚数增加率 $\alpha$ を用いて次式 て表す。

$$
\mathrm{N}_{\mathrm{y}}=(1+\alpha / 100) \mathrm{N}_{\mathrm{m}}
$$
$\alpha$ は $\mathrm{n}_{\mathrm{s} 1}, \mathrm{n}_{\mathrm{s} 2}$, ヒー夕温度および然止め張力などによっ て变化する。

第 1 加撚部の仮撚スピンドルおよび第 2 加撚部の仮㒄 スピンドル回転数をそれぞれ $\mathrm{n}_{\mathrm{f} 1} 、 \mathrm{n}_{\mathrm{f} 2}$ で表す。実験条件 として機械撚数 $2.800 \mathrm{~T} / \mathrm{m}$ としたときの $\mathrm{n}_{\mathrm{f} 1} お よ ひ ゙ n_{\mathrm{f} 2}$ の，Vに対する比を表 1 に示しだ。仮然スピンドル $\mathrm{F}_{2}$ の回転数を変化させ，ヒータ上での撚数が $2,800 \mathrm{~T} / \mathrm{m}$ お 上びそれより多い2段階の然りになるようにした。ヒー 夕の温度は120～ $220^{\circ} \mathrm{C}$ とした。ヒータ上での張力が 
Table 1 Ratio of revolution number of spindle to yarn speed at $N_{m}=2,800 \mathrm{~T} / \mathrm{m}$

\begin{tabular}{ccccl}
\hline $\begin{array}{c}\text { Twisting } \\
\text { system }\end{array}$ & $\frac{\mathrm{n}_{\mathrm{s} 1}}{\mathrm{~V}}$ & $\frac{\mathrm{n}_{\mathrm{f} 1}}{\mathrm{~V}}$ & $\frac{\mathrm{n}_{\mathrm{s} 2}}{\mathrm{~V}}$ & $\frac{\mathrm{n}_{\mathrm{f} 2}}{\mathrm{n}_{\mathrm{s} 2}}$ \\
\hline \multirow{2}{*}{$\mathrm{a}$} & \multirow{2}{*}{1400} & 1120 & 1400 & 1.0 \\
& & & & 1.1 \\
\hline \multirow{2}{*}{$\mathrm{b}$} & 935 & - & 930 & 1.2 \\
\hline
\end{tabular}

V: Velocity of feed roller $(\mathrm{m} / \mathrm{min})$

$n_{s 1}, n_{f 1}, n_{s}, n_{f 2}: r p m$ of spindles $T_{1}, F_{1}, T_{2}$ and $F_{2}$ $\mathrm{N}_{\mathrm{m}}$ : Mechanical twist number $(\mathrm{T} / \mathrm{m})$

Table 2 Properties of yarns used in this experiment

\begin{tabular}{lcccc}
\hline & A & B & C & D \\
\hline Wet Shrinkage (\%) & 7.98 & 3.87 & 1.46 & 5.56 \\
Crystallinity (\%) & 14.2 & 22.5 & 32.1 & 21.7 \\
Orientation Factor (\%) & 90.8 & 92.8 & 93.6 & 92.8 \\
Tenacity (gi/D) & 4.47 & 4.73 & 5.00 & 4.45 \\
Elongation (\%) & 36.6 & 33.1 & 30.1 & 20.7 \\
Fineness (D) & 73.6 & 73.5 & 73.3 & 74.0 \\
\hline
\end{tabular}

10，15，20，25gf となるようにトラベラの重量および 仮撚スピンドルへの糸の掛け方 ${ }^{2)}$ を調節した。なお， $\mathrm{n}_{\mathrm{s} 2}$ $=0$ の場合には本装置の第 2 加撚部のスピンドルを除去

し，巻取り装置を取付けて実験を行った。

第 1 加撚部がフライヤーレス撚糸機のものを a 型とす る。第 1 加撚部をダブルッインスタに交換したものをb 型とする。また，ダブルツィスタはフライヤーレス撚系 機に比べて一般的に生産性が高いことから工業的にはb 型が好適と考えられるが，本研究では取扱いの簡便さか ら主にa 型で実験を行った。

\section{2 試料および然系物性測定項目}

試料として 4 種類のボリエステル采 $75 \mathrm{D} / 72 \mathrm{~F}$ を使用 した。その特性を表 2 に示す。結晶化度の測定はX 線 回折装置を用いた。測定条件は前報 ${ }^{6)}$ と同様である。 A，B，Cは同一メーカ製で原料ポリマの組成も同し で，延伸熱処理条件が異なっているものである。また， Dは別のメーカのものである。撚りトルクの強さの目安 としてクリンゲルファクタを測定した。これはスナール 指数のことで, 測定方法は JIS L 1095一般紡績采試験方 法スナール指数 B 法に準じている。ただし荷重は0.5gf で行った。また，撚数およびデニール数はJIS L 1013に 涏って測定した。

\section{3. 実験結果および考察}

\section{1 機械然数と実然数について}

加撚㖘力によって然縮みに違いが生ずるので第 1 加撚 部の張力は0.2から0.25gf/D となるようにした。本装置 では第 2 加撚部での撚縮みのために実撚数が機械撚数と 異なると考えられる。図 2 に $\mathrm{n}_{\mathrm{s} 1}=\mathrm{n}_{\mathrm{s} 2}$ の条件で機械撚数 を変化させ，奏際にできた撚系の実然数 $\mathrm{N}_{\mathrm{y}}$ を測定し撚 数增加率 $\alpha$ を式（ 5 )に従って求めた結果を示す。ヒ一夕 温度は $140^{\circ} \mathrm{C}$, 撚止め張力は10gf である。2,000T/mで 既に $\alpha$ は $10 \%$ を越えており $2,500 \mathrm{~T} / \mathrm{m}$ を越えると急に増 加する。へバライン式による75Dの限界撚数は $2,837 \mathrm{~T} / \mathrm{m}$ であるが, 本装置では機械撚数 $2,500 \mathrm{~T} / \mathrm{m}$ で 既に限界然数に達しており，2,985T/m では $3,960 \mathrm{~T} / \mathrm{m}$ もの実撚りが加わっている。この系を観察すると，二重 然り発生の兆しとみられる波うつ形態が少し見られた が、二重撚りと断定できるほどではなかっった。図 3 に機 械撚数 $\mathrm{N}_{\mathrm{m}}$ を一定にして $\mathrm{N}_{1}$ と $\mathrm{n}_{\mathrm{s} 2} / \mathrm{V}$ を変化させたときの

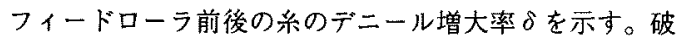
楾は第 1 加撚部で加撚されたことによるデニール增大 率, すなわちフィードローラ通過時の撚系のデニール増 大率である。実線は製造された撚系のデニール增大率で ある。原糹の実測した織度は表 2 に示したが,ここでの デニール增大率 $\delta$ は原系のデニール表示值を基準とし て, $D_{y}$ デニールの撚系では

$$
\delta=100\left(\mathrm{D}_{y}-75\right) / 75
$$

で表した。機械撚数が一定でも， $\mathrm{n}_{\mathrm{s} 1}, \mathrm{n}_{\mathrm{s} 2}$ の比を変化さ せると第 1 加撚部での撚り縮みが変化し，フィードロー

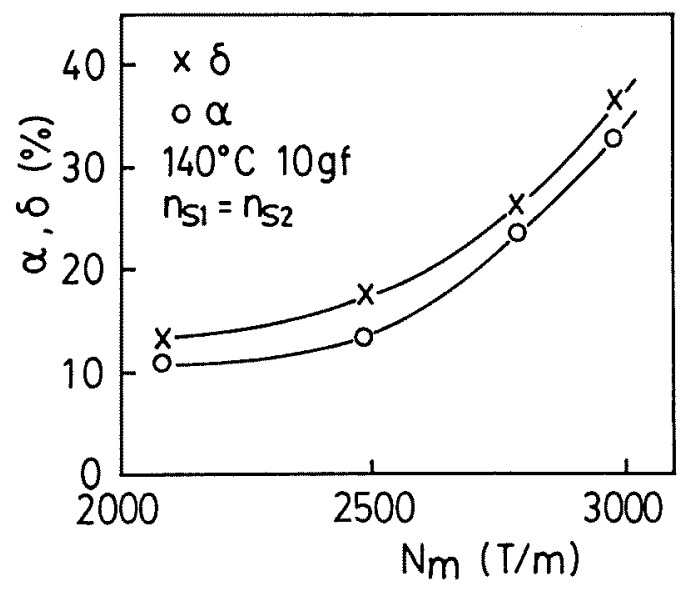

Fig. 2. Increasing rate of twist number $(\alpha)$ and denier $(\delta)$ as a function of mechanical twist number. Yarn type, $\mathrm{D}$, temperature of heater, $140^{\circ} \mathrm{C}$; and tension of the yarn on heater, $10 \mathrm{gf}$. 


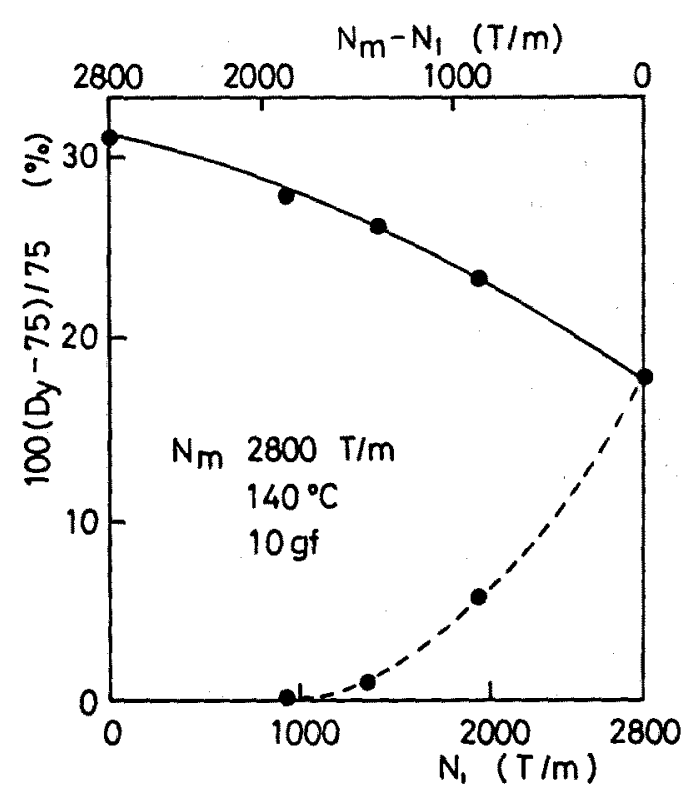

Fig. 3. Increasing rate of denier as a function of mechanical twist number at first stage $\left(\mathrm{N}_{1}\right) . \mathrm{N}_{\mathrm{m}}, 2800 \mathrm{~T} / \mathrm{m}$; yarn type, $D$; and $D_{y}$, denier of highly twisted yarn.

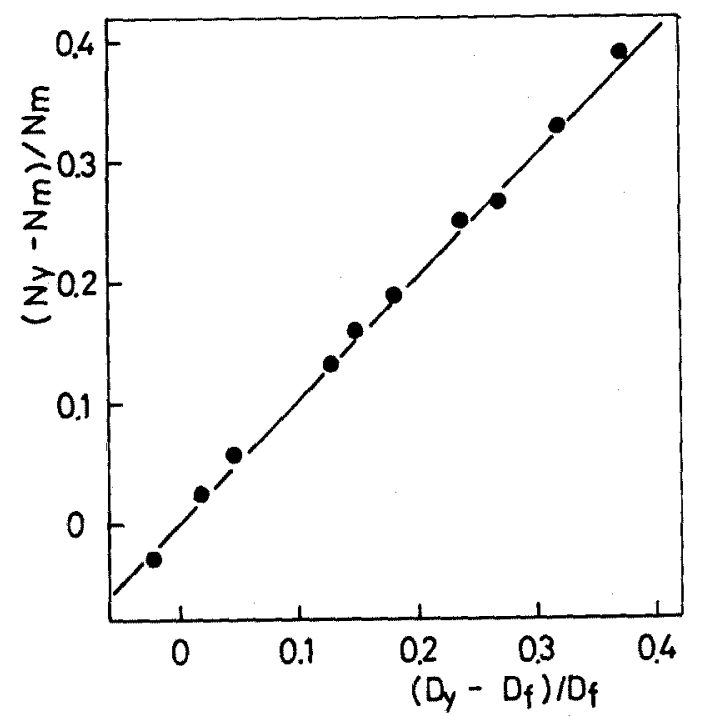

Fig. 4. Relation between increasing rate of twist number and that of denier based on denier of yarn passing the feed roller $\left(D_{f}\right)$. Yarn type, $D, N_{y}$, twist number of highly twisted yarn.

ラを通過する糸のデニール数 $D_{f}$ が異なる。さらに第 2 加撚部での撚り縮みが変化するため，結果的に撚系の寒 然数が大きく変化することになる。ここで然り止め張力 は10gf である。 $\mathrm{N}_{2}=0$ のデー夕は著者ら ${ }^{6}$ が先に報告し

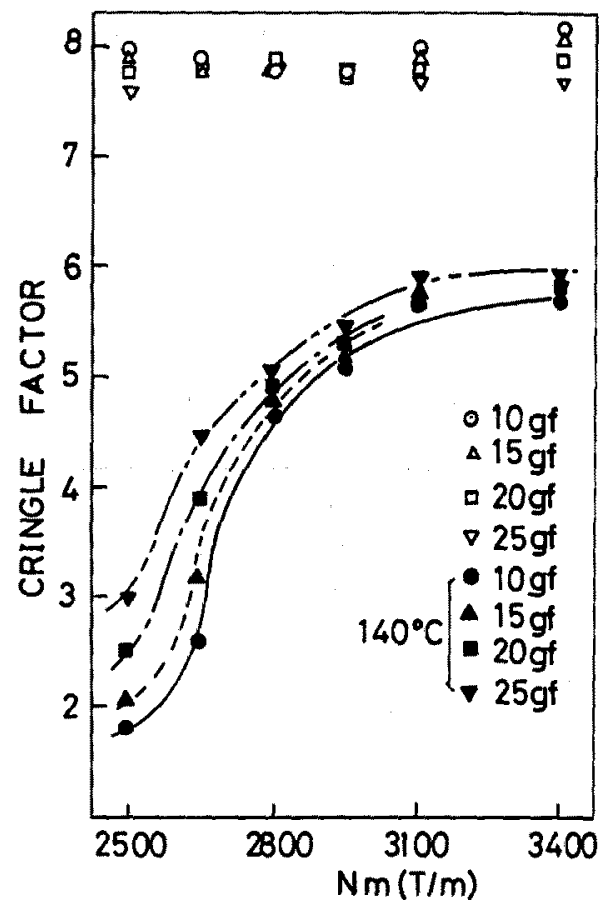

Fig. 5. Relation between cringle factor and mechanical twist number. Yarn type, D. $n_{\mathrm{t} 2} / \mathrm{n}_{\mathrm{s} 2}, 1.0 .0, \Delta, \square$, and $\nabla$. Unset highly twisted yarn under the tension of $10 \mathrm{gf}$. $15 \mathrm{gf}, 20 \mathrm{gf}$ and $25 \mathrm{gf}$, respectively. $\boldsymbol{A}, \mathbf{0}$, and $\boldsymbol{\Delta}$. Highly iwisted ya:n set on the heater at $140^{\circ} \mathrm{C}$ under the tension of $10 \mathrm{gf}, 15 \mathrm{gf}, 20 \mathrm{gf}$ and $25 \mathrm{gf}$, respectively.

\section{た装置で行ったものである。}

図 4 にフィードローラを通過する系のデニール数 $\mathrm{D}_{\mathrm{i}}$ を基準としたデニール増大率と撚数增加率の関保を示し た。フィードローラを1分間(単位時間)に通過する糸の 量とスビンドルの回転数の関係から質量 $\mathrm{D}_{\mathrm{f}} \cdot \mathrm{V} / 9000 \mathrm{~g}$ の 糸に $\left(\mathrm{n}_{\mathrm{s} 1}+\mathrm{n}_{\mathrm{s} 2}\right)$ の撚りがかけられ，V、で巻取られ， $\mathrm{D}_{\mathrm{y}}$ テ ニールの系になったとする。その撚数は次式で表され 万。

$$
\mathrm{N}_{\mathrm{y}}=\mathrm{D}_{\mathrm{y}} \mathrm{N}_{\mathrm{m}} / \mathrm{D}_{\mathrm{f}}
$$

従って次式が成り立つ。

$$
\left(N_{y}-N_{m}\right) / N_{m}=\left(D_{y}-D_{f}\right) / D_{f}
$$

図 4 を見ると，式(8)で示した通り傾き1の関係が成立 している。式( 8)を75デニール基準に書き直すと，

$$
\left(\mathrm{N}_{y}-\mathrm{N}_{\mathrm{m}}\right) / \mathrm{N}_{\mathrm{m}}=\left(75 \mathrm{D}_{\mathrm{y}} / \mathrm{D}_{\mathrm{f}}-75\right) / 75
$$

式 (9)の75/D，約 1 としてもはほ成立すると考えら れ，撚数とデニール増大率は比例すると考えても良い。 図 2，3のデニール增大率の曲線と撚数增加率の曲線が 類似のカーブを描いていることからも撚系のデニール数 と撚数は一対一に対㐫していることがわかる。従って， 
測定が简単なデニール增大率の結果から実撚数を推定で きる。

\section{2 㮒械然数と然トルク}

強撚系製造における撚止加の目的は次の製織工程での 作業性をよくすることで，撚トルク指数は重要な值であ る。強撚系織物を製造する場合に支障なく行えるための クリンゲルファクタは拉よそ3.5以下が望ましいと言わ れている。図 5 に撚数とクリンゲルファク夕の関係を示 す。七ッ卜前の撚系の場合, $2,500 \mathrm{~T} / \mathrm{m}$ か53,400T/m に至るまでクリンゲルファクタにほとんど差が現れてい ない。一方，ヒー夕温度 $140^{\circ} \mathrm{C}$ で然止めした糸の場合は $2,500,2,650 \mathrm{~T} / \mathrm{m}$ ではセット性の張力依存が見られる が2,950T/m 以上の系ではその美は明らかではなくな る。また，撚数による差も見られなくなる。

图 6 に機械撚数 $\mathrm{N}_{\mathrm{m}}$ とデニール数の関係を示した。 リンゲルファクタは図 5 のように $\mathrm{N}_{\mathrm{m}}$ が2,950 $/ \mathrm{m}$ 以上 になると頭打ちが見られたのに对して，デニール数は撚 数に対して直線的に増加している。

\section{$3.3 \mathrm{n}_{\mathrm{r} 2} / \mathrm{n}_{\mathrm{s} 2}$ と然止めトルク指数}

仮撚スピンドル回転数 $\mathrm{n}_{\mathrm{f} 2}$ 在任意に設定することによ って，2,800T/mより多い然数で撚止めを行い， $2,800 \mathrm{~T} / \mathrm{m}$ に解撚した糸のクリンゲルファクタを图 $7 に$ 示す。ヒータ温度は $140^{\circ} \mathrm{C}$ である。撚止め張力 $10 \mathrm{gf}$ の場

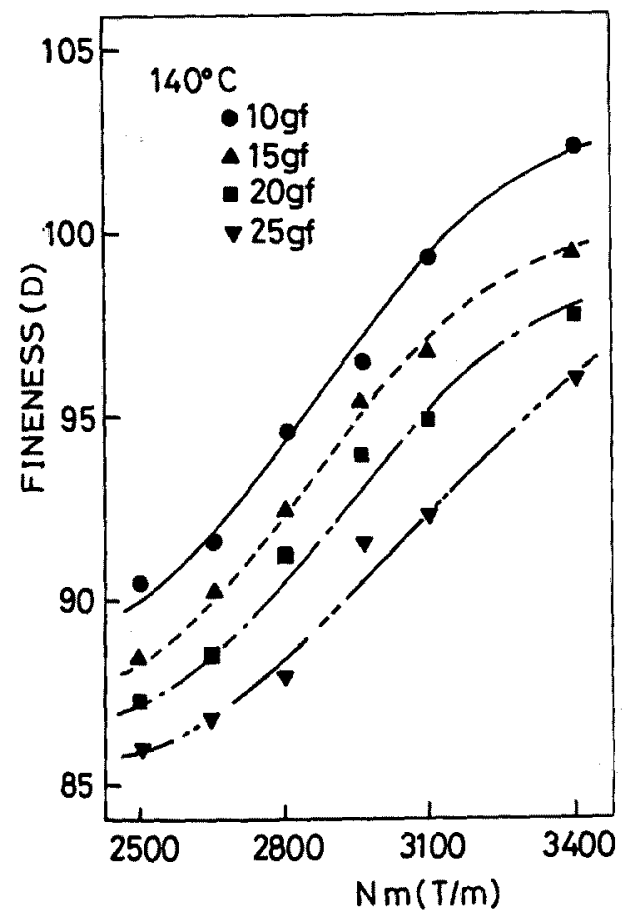

Fig. 6. Effect of tension at heater on denier of twisted yarn. The symbols are the same as shown in Fig. 5.
合、 $3,100 \mathrm{~T} / \mathrm{m}$ で撚止めし、 $2,950 \mathrm{~T} / \mathrm{m}$ に解撚するとク リンダルファクタは5.5から3.9に減少する。また $2,950 \mathrm{~T} / \mathrm{m}$ で撚止めしてから $2,800 \mathrm{~T} / \mathrm{m}$ に解然すると， クリンゲルフフクタは5.1から3.6に滅少する。のよう に撚を多くかけて撚戻しをすることによって150T/mに つきクリンゲルファク夕は約1.6滅少することがわか る。图 8 にこのときのデニール数の変化を示す。図より 撚止時に多めに撚りをかけけて最後に機械撚数が等し ければ皆同じデニール数になることがわかる。

撚系の生産速度をあげるため第 1 加撚部をダブルッィ ス夕にした装置を用いて，Dの亲について機械撚数 $2,800 \mathrm{~T} / \mathrm{m}$ としたときの $\mathrm{n}_{\mathrm{i} 2} / \mathrm{n}_{\mathrm{s} 2}$ 扩よびヒータ温度と撚卜 ルク指数の関係の結果を図 9 に示す。フィードローラを 通るときのデニール增大率は $4 \%$ 加 $7.8 \%$ になった。 Dの夈ではヒー夕温度が $140^{\circ} \mathrm{C}$ 以上になると結晶化が進 み，撚トルク発現が不良となる恐れがあるため，実用的

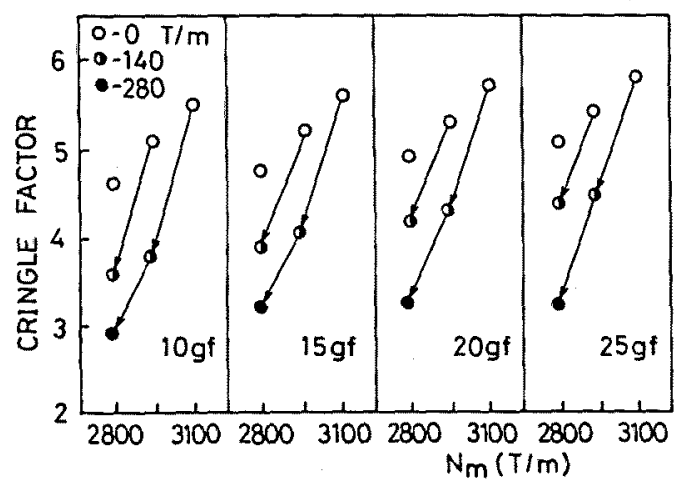

Fig. 7. Effect of untwist number after heat set on cring. le factor, Yarn type, $\mathrm{D}$; heater temperature, $140^{\circ} \mathrm{C} ; \mathrm{O}$, $\mathrm{n}_{\mathrm{f} 2} / \mathrm{n}_{\mathrm{s} 2}=1.0(0 \mathrm{~T} / \mathrm{m}) ;\left(\mathrm{n}_{\mathrm{f} 2} / \mathrm{n}_{\mathrm{s} 2}=1.1(140 \mathrm{~T} / \mathrm{m}) ;\right.$ and - $\mathrm{n}_{\mathrm{f} 2} / \mathrm{n}_{\mathrm{s} 2}=1.2(280 \mathrm{~T} / \mathrm{m})$. Numbers in parentheses are untwist numbers.

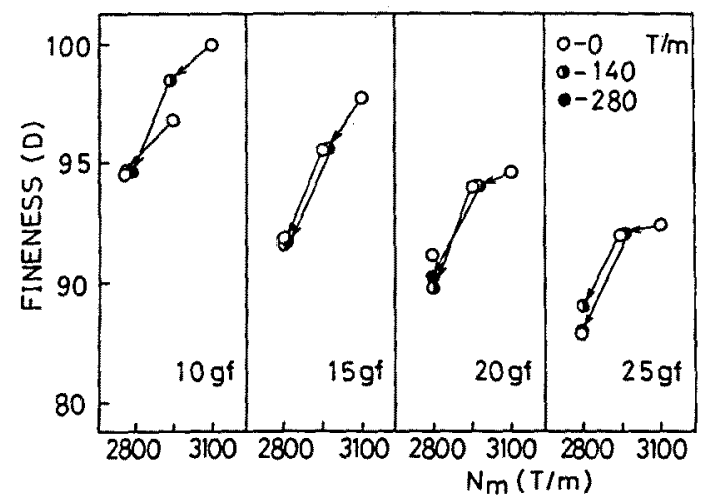

Fig. 8. Effect of untwist number after heat set on fineness. The conditions are the same as shown in Fig. 7. 


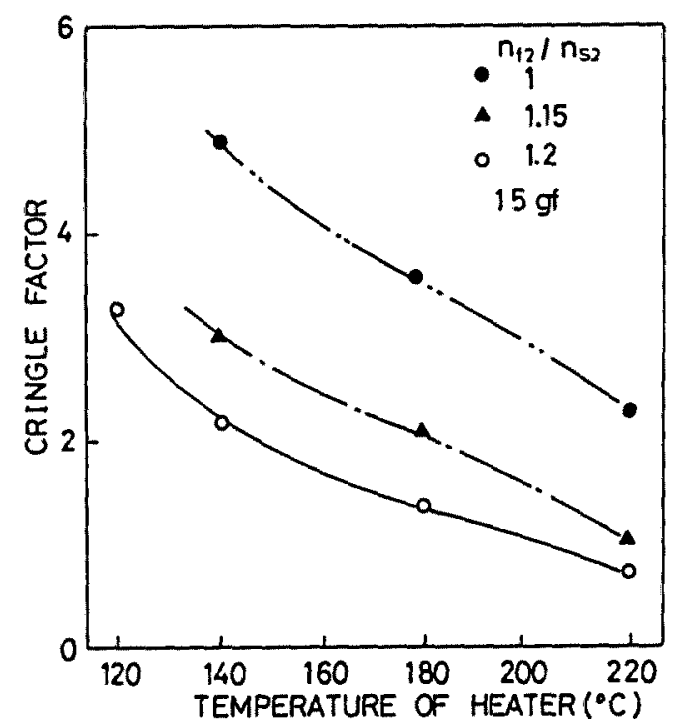

Fig. 9. Relation between cringle factor and heater temperature. This data was obtained on twisting system (b). Yarn type, D.

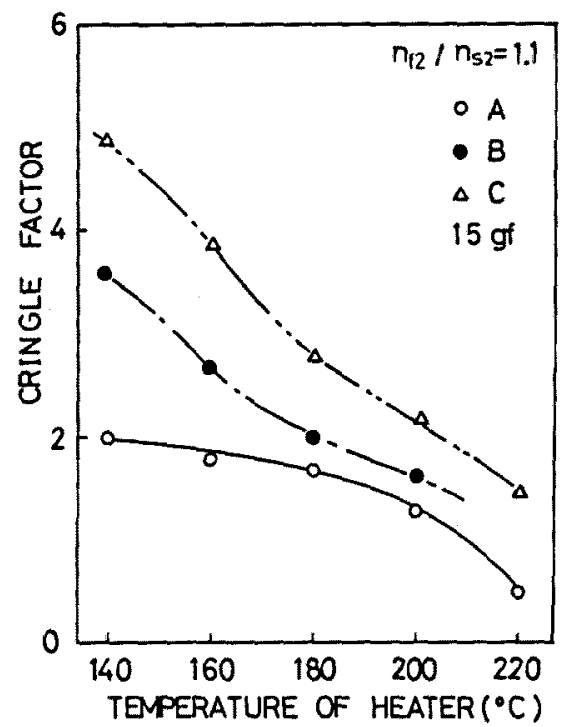

Fig. 10. Effect of crystallinity on cringle factor.

には $140^{\circ} \mathrm{C}$ 以下のヒータ温度で然止めセットを行う必要 がある。一方， $\mathrm{n}_{\mathrm{f} 2} / \mathrm{n}_{\mathrm{s} 2}=1.00$ 場合， $200^{\circ} \mathrm{C}$ 以上のヒー 夕温度で撚止めしなければクリンゲルファクタは3.5以 下にならない。しかし，图より $140^{\circ} \mathrm{C} て ゙ む \mathrm{n}_{22} / \mathrm{n}_{\mathrm{s} 2}$ を1.1 あるいは1.2とすればクリンゲルファクタを小さくする ことができ， $120^{\circ} \mathrm{C}$ と低い温度にしても充分然止めが可 能であることがわかる。また図 5の結果から撚止め張力 を小さくすれば，さらに然止如の効果を增加させること

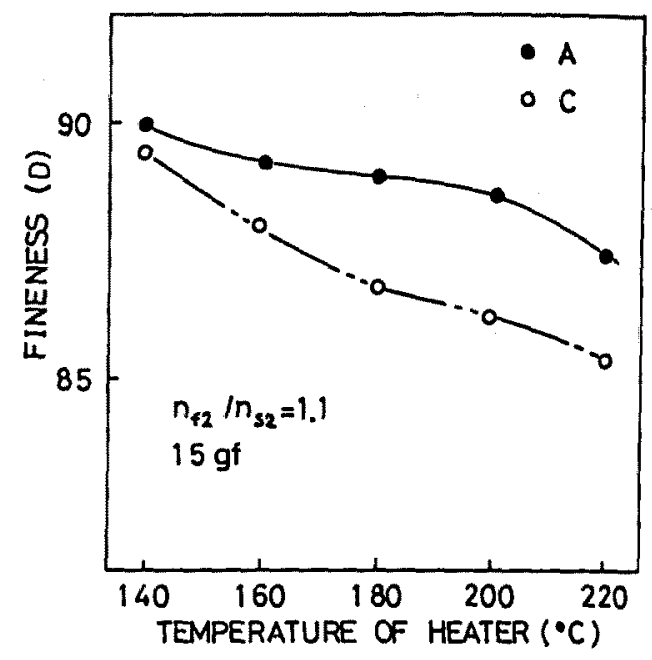

Fig. 11. Effect of crystallinity on fineness.

が期待できる。図 9 の糸の $\mathrm{n}_{\mathrm{f} 2}$ は約 $3,200 \mathrm{~T} / \mathrm{m}$ である が，著者ら ${ }^{6}$ が先に報告した装置でヒー夕温度と撚止め 張力を同一条件にして2,800T/mの撚止めを施した撚系 のトルク指数に等しい。以上のことから，本装置のよう に目的の撚数より多く撚りを加えてセットし，さらに撚 りを戻せば通常よりトルクの強さを小さく抑えることが できる。またセット温度も低くすることができるので， しば立て後のトルク発現を大きくすることが期待でき る。

\section{4 原糸の結晶化度の帛いとせット性}

撚トルクは系の結晶化度によっても翼なる。图10に $\mathrm{A} ， \mathrm{~B}, \mathrm{C}$ 系のヒータ温度とクリンゲルファクタの関 係を示した。これより同一温度に打けるセッ卜性はA

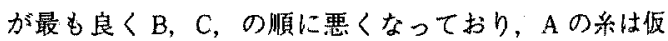
撚スピンドルの回転数の操作をしなくとも然止め効果は 十分現れている。この乎のような場合は $\mathrm{n}_{\mathrm{f} 2}$ より $\mathrm{n}_{\mathrm{s} 2}$ を大 きくし，七ットされない撚りを加えることによってトル ク発現を大きくできる可能性がある。Bの系ではせット 温度が $140^{\circ} \mathrm{C}$ 以上になると結晶化が進む少ので, 先に述 べたように $\mathrm{n}_{22} / \mathrm{n}_{\mathrm{s} 2}$ を 1 以上にしてこれより低い温度で セットすれば目的のトルクに抑えることができる。Cの 系の場合も $180^{\circ} \mathrm{C}$ で結晶化が進むため， $\mathrm{n}_{\mathrm{f} 2} / \mathrm{n}_{\mathrm{s} 2}$ を1.1か ら1.2に設定しておけば140 Cでもクリンゲルファクタ を目的值に抑えることができる。

図11にA およびCの糸のア゙ニール数とヒータ温度と の関係を示した。Aの糸は収縮が大きく、デニール数も 大きくなっている。この傾向は撚止め張力が巽なっても 同㥞であった。 


\section{4. 䊅 言}

フィラメント強㒄系の製造工程において，高速化，省 力化, ラージバッケージ化を目的として2段の撚系機構 と撚止めヒータおよび仮撚スピンドルを持つ撚系機を提 案し、この機械によって製造された强撚亲の撚糸物性を 険討した。結果は以下の通りである。

1）本実験では試作した撚系機は，従来の撚系機よりも 高速で強撚系を製造することができるとともに，ラージ パッケージ化も可能な機構である。

2) ヒータと第 2 加撚部との間に設置された仮撚スピン ドルの回転数を制御することによって，一旦設定撚数よ りも强く撚りを加えた状態でセットし，さらに設定撚数 まで解撚する。このときヒー夕温度と撚止め張力が同一 条件ならば，撚縮み，熱収縮，デニール数はほとんど変 化せずに撚トルクのみが小さくなる。

3) 上記の奻果を利用すれば，ヒー夕温度を低くしても 同一撚数，同一撚トルクの系を得ることができる。

4) 原系の結晶化度が高ければ, 相対的に撚りトルクが
大きくなるが，上記の効果を利用すれば，原系の結晶化 度の低い撚采程度に抑えることができる。

5 ）結晶化度の低い原系はど撚トルクは小さくなり，ま た収縮によってデニール数は大きくなる。

本装置によれば然りトルクを自在に変化させることが できこれまで以上の製品開発をすることが可能と考え られる。

\section{文戴}

1）松本義隆，土定育英，三谷宗久，宮本博史，織機 誌, 37, p. 471 (1984)

2 ) 山本 孝, 土定育英, 松本義隆、新宅救徳, 穖学 誌，43，320 (1987)

3 ) 北沢 亮, 特開昭60-162821

4) 戸田幸一郎, 特開昭61-8162

5 ）䊼維学会編，緎維便覧(加工編)，丸善，p. 542 (1969)

6) 山本 孝, 新宅教徳, 喜成年泰, 織学誌, 45,42 (1989) 